International Journal of Agriculture, Environment and Bioresearch

Vol. 5, No. 03; 2020

ISSN: $2456-8643$

\title{
APPRAISAL OF THE LEVEL OF ATTENTION RECEIVED BY YAM FARMING FROM THE EXTENSION AGENTS IN RIVERS AND IMO STATES, NIGERIA
}

\author{
B. A. Odinwa; I. Abali and A. N. Odinwa \\ Department of Agricultural Education,Federal College of Education (Technical),PMB 11, Omoku, Rivers State, \\ Nigeria
}

https://doi.org/10.35410/IJAEB.2020.5509

\begin{abstract}
This study appraised the level of attention received by yam farming from extension agents in Rivers and Imo States, Nigeria. Descriptive survey was employed to examine the respondents from the selected extension agencies providing the agricultural services in the two States. A proportionate random sampling was engaged to select five hundred and eighty-seven contact farmers. Data used in this study were obtained through the administration of a planned questionnaire designed in a four point Likert type rating scales. Descriptive statistics such as percentage and weighted mean scores were used to analyze the data, while $\mathrm{Z}$ - test was the inferential statistics used to test the hypothesis at $5 \%$ level of significance. The findings showed that majority of the respondents in the study areas were middle adult (46 years old), married men $(60.80 \%)$ and were more of part-time $(58 \%)$ farmers. It indicated a mean annual income of $\mathrm{N} 150,835.00$ for the farmers in the areas of study. It also showed that: planting of improved varieties $(\mathrm{M}=3.13)$, minisett technique for yam production $(\mathrm{M}=3.11)$ and planting crops in rows $(\mathrm{GM}=3.10)$, amidst other practices have received adequate attention in yam farming. However, the same result uncovered harvesting strategies of yam $(\mathrm{GM}=2.45)$, nursery practices in yam production $(\mathrm{GM}=2.41)$, organic farming technique $(\mathrm{GM}=1.99)$ and zero staking $(\mathrm{GM}=$ 1.34 ) as aspects of yam farming that have not received adequate attention in the areas. The study therefore recommended among others that: 1) Government should show more concern and make policies that will favour yam production in these States, 2) Only competent and dedicated extension agents should be employed in the field of agriculture to handle technical extension services especially in yam farming without leaving any part of yam farming untouched in these two States and 3) Let feasible rewards for distinguished extension agents be invoked to encourage hard work among extension agents in these two States.
\end{abstract}

Keywords: Appraisal, Level, Attention, Receive, Yam Farming, Extension Agents.

\section{INTRODUCTION}

Attention is the behavioural and cognitive process of selectively concentrating on a distinct aspect of information, innovations, projects or programmes suitable to their value (Vuilleumier, 2005). It may refer to things done to express interest in something as very important or done to 
arouse minds to do what is considered to be necessary. It is a key for the best possible performance of people, aiding the unfairness between stimuli and relevant and irrelevant events, projects or practices (Schunk, 2008). Attention given to any farm practice by extension agents plays a crucial role in accommodating and adopting any farm practice introduced to them. It is one of the most influential ideas employed to engage adults in meaningful ventures relating to agricultural and community development Attention can be 'Selective' in farming when it is focused on one farm practice or innovation at a time, or 'Divided' when it is focused on two farm practices/projects at once, or 'Sustained' when the practice has been focused for a long period of time and/or 'Executive' when the farm practice has been focused on completing steps to achieve a goal (Slavin, 2012). Also, attention has levels base on its impact on the practice or the people, which may be adequate, moderate, inadequate and zero or no attention. Yam farming in the areas of study is an aspect of crop farming that deserves both sustained and executive attention considering its rank among food crops in the Niger Delta. Getting and keeping farmer's attention is an important skill for any extension agents to have. When information is made personally relevant to the farmers/learners, it captivates and grabs their attention because it means something to them. When farm practice is personally relevant, farmers understand that the said farm practice or project has a purpose and is useful for them in their life (Slavin, 2012).Yam (Dioscorea spp.) is one of the essential tuber crops and a traditional food crop appreciated for its taste and cultural role in West Africa, especially in Nigeria as the world largest producers of yams, with annual production estimated at 45 million metric tons (UN Food \& Agriculture Organization, 2017, Odinwa, Isife \& Nlerum, 2019). Yam is regarded as a sociocultural crop and is becoming expensive in urban areas as its production is no longer coping with the population growth leading to Polycarp, 2001).

A recent study on yam has shown that absolute level of production in Niger Delta and the World has remained static for three decades (Scott, Rosegrant \& Bokanga, 2000). The static or dwindling trend may not be unconnected with production resources which are not being resourcefully utilized leading to low productivity of this crop (Fasasi, 2006).

The importance of yam cannot be over stretched in the Southern Nigeria. The tuber can add value when processed into crude flour by drying thin slices in the sun, then pounding and grinding them into flour, thereby empowering those that are engage in the processing. Yam enterprise can provide job opportunities to the processors and the marketers as means of livelihood, given the necessary managerial attention required at each stage.

In West Africa they are major sources of income and have high cultural value. They are used in fertility and marriage ceremonies, and special festivals are held annually to celebrate its harvest with attendant chieftaincy titles conferred on the distinguished yam farmers in most of the communities in the Niger Delta. Consumer demand for yam is generally very high in Rivers and Imo States and yam cultivation is very profitable despite the high production costs, technicalities and the riguors involved. Most starch industries use yam as one of their important and primary raw materials. It also provides income for dealer's improvement and for investment expansion. The peels serve as feed to livestock such as pigs, goats, rabbit etc. and as good component of farm yard manure (FYM). It is used as a laboratory 
crop for scientific investigations (Odinwa, et al, 2011). Vast areas of land, both upland which are lying fallow in these States can be used for yam production swamp and effectively.

Yam is majorly propagated by tuber which is also the edible part consumed by man and animals, which also lent to its scarcity and soaring cost in planting season. However, in recent time smaller portion (pieces) of yam had been introduced as minisett technology to the Nigeria farmers by the National Root Crop Research Institute (NRCRI), Umudike in 1975 and used for breeding purpose and have been found useful in ware yam production enterprise (Anyanwu, Anyanwu, \& Anyanwu, 2008).Yam generally, needs adequate nutrients for growth and development, which many cattle dung and palm bunch ash have substances such as poultry and rabbit droppings, been tested and proved to be useful and friendly alternatives to synthetic fertilizers that are both costly and unavailable at the time of need. It has also been proved that Rivers and Imo States fall within the rain forest ecological zone, which is favourable to yam and other tuber crops' production (Odinwa, et al, 2011).

Yet, yam production is still under-exploited in the States where they are highly consumed as staple and practiced as foremost and kingly occupation by the masculine farmers. From available proofs, yam farms in major parts of Rivers and Imo States are below subsistence levels as outputs are very low to meet the local demand for them, even in the face of vast fertile lands and technology, hence the dependency on the northern yam products for survival at very high costs continues to prevail in the States. Why the dwindling trend in yam products in the States that should have been championing its production? Has yam farming not received the required attention from extension agents in both States? It is wants of answers to these stirring questions that necessitated this research.

The specific objectives of this study therefore, were to:

1.describe the socio-economic characteristics of the respondents (farmers) in Rivers and Imo States, and

2. find out the extent to which yam farming has received attention from extension agents in Rivers and Imo states.

One hypothesis stated in a null form was formulated in this study to attend to the objective.

Ho: Attention received by yam farming in Rivers and Imo States from the extension agents do not differ significantly.

\section{METHODOLOGY}

Rivers and Imo States have massive fertile land and water bodies which represent those of the wet and tropical forest climate zones, with over 8,000,000 million people (Odinwa, Isife \& Nlerum, 2019). Their major occupation is farming of crops and livestock, besides huge crude oil and gas exploitation in the areas. Agencies such as: Shell Petroleum Agricultural Extension, Green River Project (GRP) of the Nigeria Agip Oil Company (NAOC) Limited, Seed Multiplication Centre (SMC) of Total E\&P Nigeria Limited and the Agricultural Development Programme (ADP) of the Ministries of Agriculture have engaged in agricultural extension in 
both tuber/root crops and livestock production for the purpose of encouraging indigenous food production and family health (Odinwa, Emah \& Odinwa, 2016).Descriptive survey was employed to examine the contact/registered yam farmers of the selected extension agencies providing the agricultural services in the two States. A total of eighteen (18) LGAs, nine (9) each from the two States were both purposively and randomly selected to achieve the objective of this study. A proportionate random sampling was finally engaged to select five hundred and eighty-seven (587) contact farmers - consisting of 316 and 271 from Rivers and Imo States respectively and used for the study. Primary data used in this study were obtained through the administration of a planned questionnaire designed in a four point Likert type rating scales of 'Adequate Attention' $(\mathrm{AA}=4)$, 'Moderate Attention' (MA = 3), 'Inadequate Attention' (IA = 2) and 'Zero Attention' $(\mathrm{ZA}=1)$, which produced a critical mean value of 2.5 for judgement, whether the attention' received by yam farming in the areas was 'adequate or inadequate. Descriptive statistics such as percentage and weighted mean scores were used to analyze the data and inferential statistics ( $\mathrm{Z}$ - test, at 5\% level of significance) was used to test the hypothesis.

\section{RESULTS}

\section{Socio-Economic Characteristics of the Respondents}

Results on socio-economic characteristics of the respondents as presented in Table1 showed that male respondents/farmers (60.80\%) dominated the study as against $(39.20 \%)$ for women, and with the average age of the respondents at 46 years old who were mostly married $(80.60 \%)$. This is because yam is regarded as a king among crops resulting from technicalities involved in its cultivation and maintenance as well as the honour accorded to it as a festival crop of rank by the male farmers. This result agreed with IITA (1982) which reported that 'Nigeria, the world's largest yam producer, considers yam to be a "man's property" and traditional ceremonies still accompany yam production indicating the high status given to the crop'.

As regards their level of education, it showed that over $90 \%$ of the respondents had formal education up to primary school as those with secondary education (48.6\%) constituted the majority in both States. This implies that the farmers in these States are not illiterates and can easily adopt innovations that can change their lives if given the opportunity. It showed that the bulk of the respondents were part - time (58\%) farmers and (42\%) as full-time farmers. This may be one of the rationales for the declining trend in yam production in Rivers and Imo States and their continued dependency on yam products from Northern Nigeria for survival. In the aspect of types of yam cultivated in the areas of study, it indicated that white yam (52.75\%) as a single crop, was predominant and followed by the combination of white yam with other yams $(29.15 \%)$. This accounts for the popularity of white yam, resulting from attention accorded it in these two States. This finding was in agreement with IITA (2008) report which claimed that out of the 600 known species of yams, that white yam, Dioscorea rotundata, purported to have originated from West Africa, is most popular. The result further presented an annual mean income of the respondents to be N150,835.00, an indication that yam farmers in the study areas are very poor and that can influence their needs in yam production. This supports the position of Odinwa, Albert and Emah (2016) and Mendola (2007) who opined that 'agricultural productions in Nigeria have been in the hands of small scale farmers who are characterized by illiteracy, use 
of local varieties of crops and poverty'.Concerning the regularity of contact of farmers with extension agents, the result showed that: once per month contact $(27.35 \%)$ was the most frequent, followed by once per week contact $(25.85 \%)$. However, $23.40 \%$ of the respondents indicated none contact with the extension agents. This level of contacts is not enough to motivate ill-considered farmers to adopt a long gestation crop farming like yam so as to boost productivity. That is why Baumgartner (2007) and Mezirow (2000) reported that "Extension agents need to know how adults/farmers define their problems, what they want to know and why they want to know, in order to design effective and innovative extension programmes", which can only be achieved through regular contact with the farmers.

Table 1: Socio-Economic Characteristics of Yam Farmers in Rivers and Imo States

\begin{tabular}{|c|c|c|c|c|c|}
\hline Variables & $\begin{array}{l}\text { Rivers } \\
\quad \mathbf{n}= \\
\text { (f) }\end{array}$ & $\begin{array}{c}\text { State } \\
316 \\
(\%)\end{array}$ & $\begin{array}{l}\text { Imo } \\
\mathrm{n}= \\
\text { (f) }\end{array}$ & $\begin{array}{c}\text { State } \\
271 \\
(\%)\end{array}$ & Mean \\
\hline Sex & (f) & $(\%)$ & (f) & $(\%)$ & \\
\hline Male & 188 & $(59.5)$ & 169 & $(62.4)$ & $60.80 \%$ \\
\hline Female & 128 & $(40.5)$ & 102 & (37.6) & $39.20 \%$ \\
\hline Age & (f) & $(\%)$ & (f) & $(\%)$ & \\
\hline $21-30$ & 15 & (4.7) & 11 & (4.1) & \\
\hline $31-40$ & 74 & $(23.4)$ & 58 & $(21.4)$ & \\
\hline $41-50$ & 131 & $(41.5)$ & 99 & $(36.5)$ & 46 Years \\
\hline $51-60$ & 66 & $(20.9)$ & 60 & $(22.1)$ & \\
\hline Others & 30 & (9.4) & 43 & (15.9) & \\
\hline Marital Status & (f) & $(\%)$ & (f) & $(\%)$ & \\
\hline Single & 54 & $(17.1)$ & 46 & $(17.0)$ & \\
\hline Married & 254 & $(80.4)$ & 219 & $(80.8)$ & $80.60 \%$ \\
\hline Others & 8 & (2.5) & 6 & $(2.2)$ & \\
\hline Level of Education & (f) & $(\%)$ & (f) & $(\%)$ & \\
\hline No Formal education & 32 & $(10.1)$ & 24 & (8.9) & $9.50 \%$ \\
\hline Primary education. & 86 & $(27.2)$ & 77 & $(28.4)$ & \\
\hline
\end{tabular}




\begin{tabular}{|c|c|c|c|c|c|}
\hline Secondary & 139 & $(44.0)$ & 146 & $(53.9)$ & $48.60 \%$ \\
\hline NCE/OND & 41 & $(13.0)$ & 12 & $(4.4)$ & \\
\hline $\mathrm{BSC}-\mathrm{PhD}$ & 18 & $(5.7)$ & 24 & (8.8) & \\
\hline Nature of Farming & (f) & $(\%)$ & (f) & $(\%)$ & \\
\hline Part Time & 121 & $((38.3)$ & 216 & $(79.7)$ & $\mathbf{5 8 \%}$ \\
\hline Full Time & 195 & $(61.7)$ & 55 & $(20.3)$ & $42 \%$ \\
\hline Types of Yam cultivated & (f) & $(\%)$ & (f) & $(\%)$ & \\
\hline White yam & 161 & $(50.9)$ & 148 & $(54.6)$ & $\mathbf{5 2 . 7 5 \%}$ \\
\hline Yellow yam & 13 & $(4.1)$ & 11 & $(4.1)$ & \\
\hline Water yam & 7 & $(2.2)$ & 07 & $(2.6)$ & \\
\hline Cocoyam & 25 & $(7.9)$ & 33 & $(12.2)$ & \\
\hline Three leaf yam & 5 & $(1.6)$ & 04 & $(1.5)$ & \\
\hline Combination & 105 & $(33.2)$ & 68 & $(25.1)$ & $29.15 \%$ \\
\hline Cropping practice & (f) & $(\%)$ & (f) & $(\%)$ & \\
\hline Sole cropping & 62 & $(19.6)$ & 39 & $(14.4)$ & $17.00 \%$ \\
\hline Inter cropping & 90 & $(28.5)$ & 131 & $(48.3)$ & $38.40 \%$ \\
\hline Mixed Cropping & 137 & $(43.4)$ & 80 & $(29.5)$ & $36.50 \%$ \\
\hline Mixed Farming & 19 & $(6.0)$ & 20 & $(7.4)$ & \\
\hline Crop Rotation & 8 & $(2.5)$ & 1 & $(0.4)$ & \\
\hline Annual Income & (f) & $(\%)$ & (f) & $(\%)$ & \\
\hline Below N120, 000 & 68 & $(21.5)$ & 72 & $(26.6)$ & \\
\hline N120,000-N180,000 & 172 & $(54.4)$ & 163 & $(60.1)$ & \\
\hline $\mathrm{N} 181,000-\mathrm{N} 240,000$ & 61 & $(19.3)$ & 35 & (12.9) & $\mathbf{N 1 5 0 , 8 3 5}$ \\
\hline $\mathrm{N} 241,000-\mathrm{N} 300,000$ & 15 & $(4.7)$ & 1 & $(0.4)$ & \\
\hline $\begin{array}{l}\text { Regularity of contact with Ext. } \\
\text { Agent }\end{array}$ & (f) & $(\%)$ & (f) & $(\%)$ & \\
\hline
\end{tabular}


Vol. 5, No. 03; 2020

ISSN: $2456-8643$

$\begin{array}{|lccccc|}\text { None } & 112 & (35.4) & 31 & (11.4) & \mathbf{2 3 . 4 0 \%} \\ \text { Weekly } & 76 & (24.1) & 83 & (30.6) & \mathbf{2 7 . 3 5 \%} \\ \text { Fortnightly } & 23 & (7.3) & 32 & (11.8) & \\ \text { Monthly } & 55 & (17.4) & 93 & (34.3) & \mathbf{2 5 . 8 5 \%} \\ \text { Bimonthly } & 21 & (6.6) & 15 & (5.5) & \\ \text { Quarterly } & 14 & (4.4) & 10 & (3.7) & \\ \text { Yearly } & 15 & (4.7) & 7 & (2.6) & \end{array}$

Source: Field Survey, 2019

Where $\mathrm{f}=$ frequency, $\%=$ percent

Extent of Attention Received by Yam Farming in Rivers and Imo States from the Extension Agents

Result of the analysis on the attention received by yam farming from the extension agents in Rivers and Imo States as shown in Table 2 indicated the aspects of yam farming that have received attention from the extension agents. These aspects in their degree of attention include: planting healthy seeds/planting materials $(\mathrm{GM}=3.20)$, planting of improved varieties $(\mathrm{GM}=$ 3.15 ), use of household labour as farm hands and minisett technique for yam production with equal grand mean $(\mathrm{GM}=3.13)$, planting crops in rows $(\mathrm{GM}=3.10)$ and use of appropriate chemical (fertilizers, pesticides, herbicides, etc $(M=3.07)$. Although, the result showed that attention given to yam farming is more in Imo State than Rivers State in all aspects.

Other aspects of yam farming that have received attention were: planting in well-drained flood free soil $(\mathrm{GM}=3.02)$, sole cropping technique and planting the required number of crop per hectare with equal mean $(\mathrm{GM}=3.00)$, ridging technique/ heap making and processing tubers into finished product like yam flour with equal grand mean $(\mathrm{GM}=2.96)$, mixed farming technique $(\mathrm{GM}=2.94)$, crop rotation technique $(\mathrm{GM}=2.91)$, commercial based method $(\mathrm{GM}=2.84)$, cooperative farming system $(\mathrm{GM}=2.82)$, mixed cropping method $(\mathrm{GM}=2.81)$, storage techniques of yam tubers $(\mathrm{GM}=2.69)$, among others. With these findings, it means that yam farming in these States has not lacked attention. Rather, the 'will' to exercise the given opportunities by farmers is what is lacking in the study areas because of the singular fact that farming in the face of crude oil exploitation and baseless politics has been relegated to the background of poverty as no rational human being (men in particular) would want to associate themselves with poverty. Except a drastic approach is taken by government with agricultural development at heart to push men into farming in these areas, it will be difficult to pull their focus out from oil and gas business and from unfounded politics.

However, the same result uncovered harvesting strategies of yam $(\mathrm{GM}=2.45)$, nursery practices in yam production $(\mathrm{GM}=2.41)$, yam/maize/vegetable intercrop $(\mathrm{GM}=2.40)$, pyramid staking 
$(\mathrm{GM}=2.29)$, organic farming technique $(\mathrm{GM}=1.99)$ and zero staking $(\mathrm{GM}=1.34)$ as aspects of yam farming that have not received adequate attention in the areas of study from the extension agents. Although, these aspects of yam farming have not received enough attention in the area, but for the fact that over 75\% of yam farming practices have received adequate attention in the areas, shouldn't have hindered yam production and productivity in these two States if there is 'a strong will' and 'ardent interest' on the side of the farmers and provision of motivation/incentives' on the side of the State governments

Table 2: Mean Distribution of the Respondents on the Level of Attention Received by Yam Farming from the Extension Agents in Rivers and Imo States

\begin{tabular}{|c|c|c|c|c|c|c|c|}
\hline & Rivers & State & Imo & State & & & \\
\hline $\begin{array}{l}\text { Attention received by } \\
\text { yam farming }\end{array}$ & $\begin{array}{c}\text { Weighted } \\
\begin{array}{c}\text { Score } \\
\mathbf{n}=\mathbf{3 1 6}\end{array}\end{array}$ & Mean & $\begin{array}{c}\text { Weighted } \\
\text { Score } \\
\mathbf{n}=\mathbf{3 1 6}\end{array}$ & Mean & $\begin{array}{l}\text { Total } \\
\text { Score } \\
\text { N = 587 }\end{array}$ & $\begin{array}{l}\text { Gran } \\
\text { d } \\
\text { Mean }\end{array}$ & Remark \\
\hline Sole cropping technique & 915 & 2.90 & 840 & 3.10 & 1755 & 3.00 & $\begin{array}{l}\text { Adequat } \\
\mathrm{e}\end{array}$ \\
\hline Mixed cropping method & 861 & 2.72 & 784 & 2.89 & 1645 & 2.81 & $\begin{array}{l}\text { Adequat } \\
\mathrm{e}\end{array}$ \\
\hline Mixed farming technique & 924 & 2.92 & 803 & 2.96 & 1727 & 2.94 & $\begin{array}{l}\text { Adequat } \\
\mathrm{e}\end{array}$ \\
\hline $\begin{array}{l}\text { Minisett technique for } \\
\text { yam production }\end{array}$ & 884 & 2.78 & 942 & 3.48 & 1826 & 3.13 & $\begin{array}{l}\text { Adequat } \\
\mathrm{e}\end{array}$ \\
\hline Crop rotation technique & 768 & 2.43 & 919 & 3.39 & 1687 & 2.91 & $\begin{array}{l}\text { Adequat } \\
\mathrm{e}\end{array}$ \\
\hline $\begin{array}{l}\text { Cooperative farming } \\
\text { system }\end{array}$ & 758 & 2.40 & 879 & 3.24 & 1637 & 2.82 & $\begin{array}{l}\text { Adequat } \\
\mathrm{e}\end{array}$ \\
\hline $\begin{array}{l}\text { Ridging technique/ Heap } \\
\text { making }\end{array}$ & 942 & 2.98 & 794 & $2 . .93$ & 1736 & 2.96 & $\begin{array}{l}\text { Adequat } \\
\mathrm{e}\end{array}$ \\
\hline $\begin{array}{l}\text { Nursery practices in yam } \\
\text { production }\end{array}$ & & & 729 & & 1398 & & Inadequa \\
\hline www.ijaeb.org & & & & & & & age 112 \\
\hline
\end{tabular}


Vol. 5, No. 03; 2020

ISSN: $2456-8643$

\begin{tabular}{|c|c|c|c|c|c|c|c|}
\hline & 669 & 2.12 & & 2.69 & & 2.41 & te \\
\hline Zero staking & 421 & 1.33 & 363 & 1.34 & 784 & 1.34 & $\begin{array}{l}\text { Inadequa } \\
\text { te }\end{array}$ \\
\hline Pyramid staking & 642 & 2.03 & 692 & 2.55 & 1334 & 2.29 & $\begin{array}{l}\text { Inadequa } \\
\text { te }\end{array}$ \\
\hline Sole yam staking & 713 & 2.26 & 744 & 2.75 & 1457 & 2.51 & $\begin{array}{l}\text { Adequat } \\
\mathrm{e}\end{array}$ \\
\hline $\begin{array}{l}\text { Small Plot Adoption } \\
\text { Technique }\end{array}$ & 714 & 2.26 & 823 & 3.04 & 1537 & 2.65 & $\begin{array}{l}\text { Adequat } \\
\mathrm{e}\end{array}$ \\
\hline $\begin{array}{l}\text { Use of household laboul } \\
\text { as farm hands }\end{array}$ & 962 & 3.04 & 870 & 3.21 & 1832 & 3.13 & $\begin{array}{l}\text { Adequat } \\
\mathrm{e}\end{array}$ \\
\hline $\begin{array}{l}\text { Use of paid labour as } \\
\text { farm hands }\end{array}$ & 876 & 2.77 & 793 & 2.93 & 1669 & 2.85 & $\begin{array}{l}\text { Adequat } \\
\mathrm{e}\end{array}$ \\
\hline $\begin{array}{l}\text { Use of appropriate } \\
\text { (fertilizers, pesticides, } \\
\text { herbicides, etc) }\end{array}$ & 851 & 2.69 & 933 & 3.44 & 1784 & 3.07 & $\begin{array}{l}\text { Adequat } \\
\mathrm{e}\end{array}$ \\
\hline $\begin{array}{l}\text { Subsistence based } \\
\text { farming }\end{array}$ & 756 & 2.39 & 843 & 3.11 & 1599 & 2.75 & $\begin{array}{l}\text { Adequat } \\
\mathrm{e}\end{array}$ \\
\hline $\begin{array}{l}\text { Organic farming } \\
\text { technique }\end{array}$ & 733 & 2.32 & 450 & 1.66 & 1183 & 1.99 & $\begin{array}{l}\text { Inadequa } \\
\text { te }\end{array}$ \\
\hline $\begin{array}{l}\text { Commercial based } \\
\text { method }\end{array}$ & 786 & 2.49 & 863 & 3.18 & 1649 & 2.84 & $\begin{array}{l}\text { Adequat } \\
\mathrm{e}\end{array}$ \\
\hline $\begin{array}{l}\text { Planting in well-drained } \\
\text { flood free soil }\end{array}$ & 839 & 2.66 & 915 & 3.38 & 1754 & 3.02 & $\begin{array}{l}\text { Adequat } \\
\mathrm{e}\end{array}$ \\
\hline $\begin{array}{l}\text { Planting of improved } \\
\text { varieties }\end{array}$ & 880 & 2.78 & 955 & 3.52 & 1835 & 3.15 & $\begin{array}{l}\text { Adequat } \\
\mathrm{e}\end{array}$ \\
\hline
\end{tabular}


Vol. 5, No. 03; 2020

ISSN: $2456-8643$

Planting the required

number of crop per

hectare

859

2.72

3.28

889

1748

3.00

Adequat

Planting healthy

seeds/planting materials

896

2.84

3.55

1858

3.20

Adequat

962

3.42

Planting crops in rows

876

2.77

928

1804

3.10

Adequat

$\mathrm{e}$

Keeping farm weed-free

871

2.76

3.55

961

1832

3.16

Adequat e

Yam/maize/vegetable

intercrop

681

2.16

2.63

712

1393

2.40

Inadequa te

Harvesting strategies of

715

2.26

2.64

yam

715

1430

2.45

Inadequa

te

Processing tubers into

finished product like yam

flour

848

2.68

3.23

2.96

Adequat

875

1723

$\mathrm{e}$

Storage techniques of yam tubers

771

2.44

2.93

793

1564

2.69

Adequat
e

Linking farmers to

Marketing Boards

787

2.49

2.83

766

1553

2.66

Adequat
$\mathrm{e}$

Source: Field Survey, 2019

Decision Mean $=2.50$

The $\mathrm{z}$ - test result on the level of attention received by yam farming from the extension agents in Rivers and Imo States as shown in Table 3 put $(\mathrm{z}-\mathrm{cal}=6.77$ and $\mathrm{z}-$ critical $=1.96)$ at a probability level less than $0.05 \%$. The hypothesis which stated that 'the attention received by yam farming from the extension agents in Rivers and Imo States do not differ significantly' was rejected, implying that the attention received by yam farming in Rivers and Imo States from the extension agents differed significantly. These differences on the attention received by yam 
farming in Rivers and Imo States from the extension agents may be due to agrarian interest of the two State governments, the competence level of the extension agents working in various LGAs, farming programmes or objectives of the extension agencies (governmental or non governmental) and the encouragements received by the extension agents from their agencies and from the farmers/clients or the community. It was on the plight of the competence level of extension agents that Ejiogu-Okereke and Onu (2007) recommended that qualified extension agents be recruited and encouraged to develop meaningful work experience for farming; that international donor agencies concerned in agricultural development should guarantee adequate budgetary arrangement to accommodate extra costs involved in extension agent's participation activities and that the Agricultural Development Programme should show more concern for staff welfare to enhance adequate commitment to organizational goals and Extension Services generally.

Table 3: Z-test Result of the Respondents on the Levels of Attention Receive by Yam Farming from the Extension Agents in Rivers and Imo States

\begin{tabular}{|lccccccc|}
\hline Source & N & Mean & df & Variance/Sd & z-cal & z- tab & Remark \\
\hline Rivers & 316 & 32.76 & 585 & $76.62 / 8.75$ & & & \\
Imo & 271 & 37.18 & & $49.73 / 7.05$ & & & \\
Total & 587 & & & & 6.77 & 1.96 & S \\
\hline
\end{tabular}

Source: Field Survey, 2019

'S' Means Significant at $\mathrm{P}<0.05 \%$

\section{CONCLUSION}

Attention received by yam farming from the extension agents in both Rivers and Imo States was adequate to encourage yam farming, though it was not sustained in the long-run. But the attention received by yam farming differed considerably between the two States in favour of Imo State, which resulted from different agrarian interest of the two State governments; differences in farming objectives of the extension agencies (governmental or non - governmental) and the kind of encouragements received by the extension agents from their agencies and from the farmers/clients or the communities within these States.

\section{RECOMMENDATIONS}

The study based on the findings, recommended the following:

1. Government should show more concern and make policies that will favour yam production in these States, 
2. Only competent and dedicated extension agents should be employed in the field of agriculture to handle technical extension services especially in yam production without leaving any part of yam farming untouched in these two States,

3.Let feasible rewards for distinguished extension agents be invoked to encourage hard work among extension agents in these two States, and

4. Women and youths should be skillfully and financially motivated to engage in yam production by the State governments and non-governmental organizations interested in agriculture in these two States.

\section{REFERENCES}

Anyanwu, A.C., Anyanwu, B.O. \& Anyanwu, V.A. (2001). A text book of agricultural science for School and Colleges. Nigeria: Africana-Feb Publishe Limited.

Baumgartner, L. (2001). An update on transformational learning. In The new update on adult learning theory: New directions for adult and continuing education,

89. San Francisco: Josey-Bass.

Ejiogu-Okereke, N.E. \& Onu, D.O. (2007). Perceived factors affecting performance of extension workers in Imo State, Nigeria: Global Approaches to Extension

Practice. A Journal of Agricultural Extension. 3(1). 21-29.

Fasasi, A.R. (2006). Resource use efficiency in yam production in Ondo State, Nigeria. Agricultural Journal, 1(2): 36-40.

IITA (International Institute of Tropical Agriculture) (1982). Annual Report International institute of Tropical Agriculture, Ibadan, Nigeria.

IITA (International Institute of Tropical Agriculture (2008). AGXE analysis provides vital insight for IITA crops. IITA Research. 12-29.

Kushwaha, S. \& Polycap, I.M. (2001). Economics of Small Scale Yam Production in Quaian Pau L.G.A. of Plateau State. Proceedings of 39th Annual Conference of ASN, ATBU, Bauchi, October 15-19. 69-74.

Mendola, M. (2007). Migration and technological change in rural households: Complements or substitutes. Journal of Development Economics. 24(1). 49-68.

Mezirow, J. (Ed.). (2000). Learning as transformation: Critical perspectives on a theory in progress. San Francisco: Jossey-Bass.

Odinwa, A. B, Alali, N. E, Abali, I, Ahiakwo, A. A. \& Odinwa, A. N. (2011). Economic viability of yam minisett production and the problems affecting minisett enterprise in 
Vol. 5, No. 03; 2020

ISSN: $2456-8643$

Ogba/Egbema/Ndoni Local Government Area of Rivers State, Nigeria. Mediterranean Journal of Social Science. Special Issue. 2:115 - 121.

Odinwa, A. B., Emah, G. N. \& Odinwa, A. N. (2016). Challenges of Rabbit Farming in Ogba/Egbema/ Ndoni Local Government Area of Rivers State. Intenational

Journal of Agriculture and Earth Science, 6-13.

Odinwa, A. B., Albert, C. O. \& Emah, G. N. (2016). Assessment of agro-credits available to farmers' in Orashi Region of Rivers State, Nigeria. Journal for Applied Research (JFAR), 8 (1). $77-94$

Odinwa, A. B., Isife, B. I. \& Nlerum, F. E. (2019). Analysis of the extension needs of yam farmers for increased productivity in Rivers and Imo States, Nigeria. International Journal of Agriculture, Environment and Bioresearch. 4(6). 162 - 178.

Schunk, D. H. (2008). Learning Theories: An Educational Perspective. New Jersey: PearsonPrentice Hall.

Scott, G. J. R., Rosegrant, M. \& Bokanga, M. (2000). Roots and tubers in the Global Food System Vision Statement of Year 2020. International Potato Centre, Lima Peru. 67-70.

Slavin, R. E. (2012). Educational Psychology: Theory and Practice. (10). 6.

UN F.A.O. (2017). UN's decision to create a decade on family farming, a World Bee Day, a day promoting awareness of the need to combat illegal fishing, and declare international years for camelids and sustainable fisheries.21-12-2017.

Vuilleumier, P. (2005). How brains beware: neural mechanisms of emotional attention: Trendsin Cognitive Science,(9).12. 